\title{
The Anxiety of Children's Future in Parents Who Have Children With Autism Spectrum Disorder
}

\author{
$1^{\text {st }}$ Tri Winarsih \\ Master of Psychology Study Program \\ Universitas Aisyiyah Yogyakarta \\ Yogyakarta, Indonesia \\ triwinarsih@unisayogya.ac.id
}

\author{
$2^{\text {nd }}$ Zahro Varisna Rohmadan \\ Master of Psychology Study Program \\ Universitas Aisyiyah Yogyakarta \\ Yogyakarta, Indonesia \\ zahrovarisna@unisayogya.ac.id
}

\begin{abstract}
This study aims to determine whether parents have anxiety about the children's future diagnosed with autism spectrum disorders. Children with autism spectrum disorder have more complex characteristics than the children with special need, so that parenting has its own challenges. This research was conducted using a survey method by providing a scale of anxiety about the children's future to the subject. The subjects consisted of 10 (ten) mothers of children with autism spectrum disorders.The result showed that 9 (nine) people experienced anxiety in the moderate category, and one (1) person experienced anxiety in the low category. The subjects who have moderate level of anxiety in the cognitive aspects, such as negative thoughts about the children's future who are considered unable to live a normal life like other individuals. Future research is expected to be able to provide interventions to reduce anxiety in parents of the children with autism spectrum disorders, because the anxiety experienced by parents will affect the quality of care for the children.
\end{abstract}

Keywords - future-anxiety, autism spectrum disorders, parenting of autistic children

\section{INTRODUCTION}

The hope of every parent is to have children who are physically and psychologically healthy. However some parents have children with special needs, such as mental retardation, deafness, the children with attention deficit/hyperactivity disorder, the children with autism spectrum disorder (ASD) and others. Each special need children has their own characteristics. The children with ASD have more complex characteristics than other special need children [1]. The diagnostic and statistical manual of mental disorders fifth edition (DSM V) states that the children with ASD have certain characteristic, such as the difficulties in communicating and interactions socially, and having interests behaviors that are rigid and repetitive [2]. This is supported by the results preliminary studies conducted by researchers. The preliminary study was carried out by conducting interviews with 10 (ten) parents of ASD children and 10 (ten) ASD children at The DIY (Daerah Istimewa Yogyakarta) Autism Service Center. The results of the preliminary study revealed data on some of the behaviors shown by ASD children, namely, the difficulty of understanding other people conversations, and the difficulty of expressing their emotions, so that when anger is expressed in appropriately, for example hitting others or yourself and breaking things. This communication difficulty also affects parents and teachers, namely, having difficulty teaching learning materials. In addition, the difficulty of communicating and interacting socially causes parents to have difficulty teaching independence in carrying out daily activities. ASD children also show behavior that they do not understand the social norms that apply in society. Therefore, it is not uncommon for ASD children to be considered impolite or violate the norms prevailing in society.

The characteristic of the two ASD children are stiff interest and repetitive behavior. This also causes difficulties in parenting by parents. For example: a child who cannot accept changes in their routine of their life, for example if the route changes, the child becomes hysterical when the route to school changes. Another example is ASD children who are sensitive to sound or light, when they hear certain sounds, they become angry and hysterical. But on the other hand, some extraordinary talents or abilities that exceed children in general. For example: ASD children who are able to memorize hundreds of songs and able to produce painting with high selling value, are able to observe things in great detail, obey the rules and so forth. Based on the result of interviews with parents, especially mothers, it was found that the complex characteristic of ASD children caused mother to experienced difficulties in caring for ASD children. Mothers stated that they feel anxious about the future of their children. They are often affected by negative emotions when ASD children are difficult to control, feel frustrated whether the child's condition can grow well like other children?

Based on the data from the previous study, it can be concluded that parents have difficulty in caring for ASD children. Parenting is a process to provide the need of child's life, education, love, care and well-being in order to able to grow and develop well in physically, socially, emotionally, intellectually and spiritually [3]. The difficulty interacting with ASD children is a separate stress in child's care, so the case of ASD children is a double burden for parents of ASD children [4]. Parents know that their child's development is not like other children, so that the anxiety can arise about child's future. Is the future of his child going well like the other children? The parents' anxiety about the future of their children is natural, because the parents have an inner bond with their children and try to provide the best possible care and education for their children.

Feist and Feist stated that anxiety is unpleasant condition, emotional and its strength can be felt, and usually comes with physical sensations (sensations in the body) as a sign 
that a danger will attack them [5]. This uncomfortable condition is usually not clearly felt by the individual who experiences it. Meanwhile Durand and his friends define anxiety as a mood or certain conditions characterized by symptoms in the limbs. For example psychical tension and negative thoughts about the future [6].

Alwisol further explained that anxiety is the result of conflict in individual life, but it is very useful to warn an individual that the danger will come [7]. Seminun said there are 4 (four) aspects of anxiety, namely; aspects of mood, cognitive aspects, somatic aspects and motor aspects [8]. The first aspect is mood, which is included in the mood aspects, namely; feeling and panic, worry, tension, irritability. Anxious individuals usually predict that a disaster or a punishment will threaten them. The second aspect is cognitive that is, there is a concern that comes from the individual thoughts about the disaster that is considered to occur, and then the individual has a plan to avoid it. The third aspect is somatic which can occur either directly or indirectly. The direct somatic aspects are such as a faster heartbeat, profuse sweating, dry mouth and muscle tension. The indirect somatic aspect, for example when feeling prolonged anxiety, as a result, digestion becomes disturbed, causing diarrhea or constipation. The fourth aspect is motor or movement in the limbs. An example of the motor aspect is when feeling anxiety unconsciously and the individual squeezes his own hand, pressing the ball point button or tapping his finger on the table. Symptoms of each aspect of anxiety will appear differently in each individual.

Rohmadani \& Warastri mentioned that people with disabilities have concern about their future. Are they able to live independently and achieve the success that they expect? [9]. In addition, the researcher conducted by Sari and Dewi found that mothers of children who are deaf, have control over their children's future. Because the children with hearing impairment have difficulty in communicating verbally, and parents feel job vacancy for deaf people is hard to find $[10]$.

Meanwhile ASD children have more complex characteristics than children with hearing impairment. Besides having difficulties in socializing and have specific rigid interests because the characteristics are unique also the parents have bigger obstacles to be able to communicate with ASD children fluently. Because of that, researchers want to see whether the parents of ASD children also have a future for their children.

\section{RESEARCH METHOD}

The method used in this research is a survey research method which is further deepened by conducting interviews with the subject as additional data. The survey research method is a research by collecting data from a sample to represent the entire population with a natural setting than the data collection tool uses a questioner $[11,12]$

The population is a group of subjects who will be subjected to generalization of research result. The subject group as a population must have the same character, and be able to differentiate from other subject groups [13]. The populations in this study were mothers who had ASD children and resided in Yogyakarta. After the population responded, the research sample was determined. The sample is part of the population, which of course has the characteristic of population. How the sample represents the population, then in sample selection, subjects who have similar characteristics must be selected with the population [13]. This research used a sample of 10 [ten] mothers who have ASD children and who live in Yogyakarta.

The data collection tool in this survey research method is questioner which aims to reveal the variables that the researcher wants to know [11]. The questioner which is used in this study is the parent anxiety scale for the future of children. The scale was compiled by the researcher, with reference to the theoretical concept put forward by Semiun [8].

\section{A. Conceptual definition.}

Semiun mentions there are 4 (four) anxiety aspects [8]. First, mood aspect which consists of tension, worry, panic, irritability. An anxious person has a feeling of a threatening disaster law from something is usually unknown source. Second, the cognitive aspect which refers to a disaster matters or concern and planning how to avoid them. The somatic aspect which consists of two kinds aspects namely; direct and indirect aspect. The direct aspect such as sweating, dry mouth, shortness of breath, faster pulse, increased blood pressure, head throbs and the muscle become tense. The indirect aspect is that when the anxiety is prolonged. It causes chronic and increased blood pressure, headaches, difficult digestion, and pain in the stomach.

Fourth, the motor aspect. In this aspect, example of motor activity in anxious people includes tapping toes, plucking eyebrows or biting nails. Motor activities which are carried out by anxious people are a high cognitive and somatic picture of a person and an attempt to protect oneself from something that threatens the individual.

\section{B. Operational definition}

Anxiety about a child future consist of 4 (aspects) namely:

\section{1) Mood aspect}

Include feeling tense, worried, panic, irritate when thinking or talking about the future of ASD children.

\section{2) Cognitive aspect}

Namely having concern about the children's future and having plan how to prevent bad future of the children.

\section{3) Somatic aspect}

Somatic aspect concerns of two kinds, namely direct and indirect somatic aspect. The direct somatic aspect includes sweating, shortness of breath and dry mouth. The indirect aspect is that when you fell prolonged anxiety, it will cause your blood pressure increased, pain and digestion becomes disturbed.

\section{4) Motoric aspect}

When an individual feels anxious, a reaction occurs in the movement of his limbs, for example: walking back and forth, tapping his fingers, tapping the soles of his feet on the floor and biting his fingers nails. 


\section{RESULT AND DISCUSSION}

The following are the results of anxiety scores on the subject.

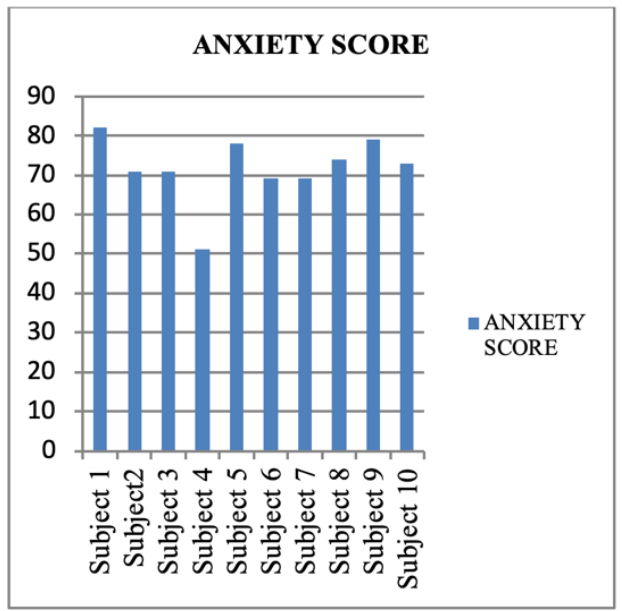

Fig. 1. Subject anxiety score

The scores categories are as follows;

$\begin{array}{ll}\text { Very high } & :>105,4 \\ \text { High } & : 86,9-105,4 \\ \text { Medium } & : 68,3-86,8 \\ \text { Low } & : 49,6-68,2\end{array}$

Very low $\quad: 49,5$

Based on the graph above, it can be seen that 9 (nine) subjects experienced anxiety in the moderate category, namely; 1, 2, 3, 5, 6, 7, 8, 9 and 10 . While one subject namely subject 4 has anxiety in the low category. Therefore, it can be concluded that mothers of ASD children have anxiety about the future their ASD children. This also happens to mothers who have deaf children. Sari and Dewi found that mothers have concern about the future of their deaf children, because deaf children have difficulties in communicating, so they are considered to have difficulties in all aspects of their lives. Including the difficulty of getting a job, because mothers see that employment opportunities for deaf individuals are very limited. However, Sari and Dewi found that mothers with other deaf children do not have anxiety about the future of their children but it is rather because of the support from their family or close people who are ready to provide work for their children [10].

Furthermore, the researcher conducted interviews with the subjects to obtain additional data regarding the details of the subject anxiety. The result is that the majority of subjects who have anxiety are in the moderate category, showing anxiety in the cognitive aspects. Anxiety which is shown in the cognitive aspect subject is an emergence of negative thoughts about the future of their child. The subject was worried that if the parents had died, then the child would not be cared for. So that the subject was worried about how the child's life would be after the parents died because no one took care of him/her anymore. Another negative thought is that his ASD child is unable to lead a normal life like other individuals who are not ASD. There is a concern that his child is unable to work so that he is unable to fulfill his own needs. Then the question rises whether his child is able to build a household. The subject admitted that the condition of ASD children had many obstacles, so that they were worried whether in the future the children would be able to live happily or not.

\section{CONCLUSION}

Based on the results of the research and discussion above, it can be concluded that parents of ASD children have anxiety of the future of their children, especially anxiety that appears in the cognitive aspect. Namely; having various kinds of worries or negative thoughts about the child's future which they suspect will not go well. Suggestion

\section{1) For parents of ASD children.}

Parents of ASD children are expected to be able to manage their thoughts, so that there is no great anxiety about their child future. Parents need to learn techniques to reduce anxiety.

\section{2) For future researcher.}

Based on the results of this study, it is hoped that there will be further studies on effective intervention techniques to reduce anxiety in parents of ASD children. Therefore, parental anxiety can reduce the quality of care to ASD children.

\section{REFERENCES}

[1] Daulay, N., "Gambaran Ketangguhan dalam Mengasuh Anak Autis," Psikohumaniora: Jurnal Penelitian Psikologi, Vol.1, No.1, p.49-74, 2016.

[2] American Psychiatric Association, Diagnostic and Statistical Manual of Mental Disorder Fifth Edition (DSM V), Washington, DC: American Psychiatric Association, 2013.

[3] Yunus, K.R.M. \& Dahlan, N.A., "Child-rearing Pactices and Socioeconomic Status: Possible Implications for Children's Educational Outcomes," Procedia-Social and Behavioral Science, Vol. 90, p.251259, 2013.

[4] Mukhtar, D.Y., dkk., "Psychoeducation Group for Parents Who Raise A Child with Autism Spectrum Disorder," Couns-Edu. The International Journal of Counseliing and Education, Vol. 3, No.1, p.28-33, 2018.

[5] Feist, J.; Feist, G., Teori Kepribadian, Buku 2 Edisi 17, Jakarta: Salemba Humanika, 2012

[6] Durand, V.M.; Barlow, D.H., Intisari Psikologi Abnormal, Edisi IV, Yogyakarta: Pustaka Pelajar, 2006.

[7] Alwisol, Psikologi Kepribadian, Malang: UMM Press, 2006

[8] Semiun, Y., Kesehatan Mental, Yogyakarta: Kanisius, 2010.

[9] Rohmadani, Z.V.; Warastri, A., IbM Penanganan Kecemasan Menghadapi Masa Depan pada Difabel Daksa Kalayan Balai Besar Rehabilitasi Sosial Bina Daksa Prof.Dr.Soeharso Surakarta, Laporan Program Hibah Pengabdian Kompetisi : tidak diterbitkan, 2016.

[10] Sari, N.P.R. \& Dewi, D.K., "Perbedaan Tingkat Kecemasan Masa Depan Karir Anak Ditinjau dari Self-Concept dan Persepsi Dukungan Sosial pada Ibu Anak Tunarungu di SMALB-B Karya Mulia Surabaya," Character, Vol. 1, No. 1, 2013.

[11] Singarimbun, M \& Effendi, S., Metode Penelitian Survai, Jakarta: LP3ES, 2006.

[12] Sugiyono, Metode Penelitian Pendidikan, Bandung: Alfabeta, 2012

[13] Azwar, S., Metode Penelitian, Yogyakarta: Pustaka Pelajar, 2001. 